DOI 10.14746/ssp.2015.1.1

\author{
Wojciech Tomasz MODZELEWSKI
}

Uniwersytet Warmińsko-Mazurski

\title{
Polsko-rosyjskie pogranicze - od regionu izolowanego do transgranicznego
}

\begin{abstract}
Streszczenie: W artykule przyjęto założenie, że dwa regiony sąsiadujące, czyli posiadające wspólną, lądową granicę: województwo warmińsko-mazurskie i Obwód Kaliningradzki FR tworzą polsko-rosyjskie pogranicze. Widoczna jest ewolucja polsko-rosyjskiej granicy: od zamkniętej (do 1955 r.), poprzez selektywnie otwartą (lata 1956-1989), do granicy jako płaszczyzny współpracy (od 1990 r.). Wpływa to na ewolucję badanego pogranicza: od zamkniętego, izolowanego - do pogranicza, gdzie realizowane są wielowymiarowe, oddolne kontakty transgraniczne. Natomiast wprowadzenie w 2012 r. zasad małego ruchu granicznego i związany z tym dynamiczny wzrost ruchu granicznego służą kształtowaniu polsko-rosyjskiego regionu transgranicznego.
\end{abstract}

Słowa kluczowe: polsko-rosyjskie pogranicze, współpraca transgraniczna, ruch graniczny

Drzyjmując kryterium regionalnych jednostek zasadniczego podziału administracyjnego kraju (polityczno-administracyjne), za pogranicze polsko-rosyjskie uznano terytorium Obwodu Kaliningradzkiego FR oraz województwa warmińsko-mazurskiego ${ }^{1}$. Są to dwa regiony sąsiadujące, tj. posiadające wspólną, lądową granicę. Między innymi ze względu na wspólne dziedzictwo historyczne oraz rolę polityczną założono, że tworzyć one mogą potencjalny obszar współpracy transgranicznej, definiowanej jako - współpraca sąsiedzka, prowadzona poprzez wspólną granicę (ponadgraniczna) $\mathrm{w}$ ramach przylegających do siebie regionów przygranicznych (granicznych, nadgranicznych), tworzących wspólne pograni-

1 Spotkać można odmienną delimitację tego pogranicza, np. Tadeusz Palmowski wlicza doń także województwo pomorskie (Pogranicze, 2007). Wyznaczenie pogranicza według regionalnych jednostek administracyjnych, funkcjonujących po obu stronach granicy jest powszechne w literaturze przedmiotu (zob. Borys, 2000, s. 79; Pogranicze, 2005). Mimo ugruntowania w literaturze przedmiotu określenia ,ppogranicze polsko-rosyjskie”, wskazać można pojedyncze przypadki, w których neguje się zasadność jego stosowania (zob. Żelazny, 2002, s. 125). 
cze (por. Modzelewski, Żukowski, 2013, s. 36). Współpraca ta przybiera różnorodne formy; od zinstytucjonalizowanych euroregionów, kooperacji partnerskiej oraz nieformalnej jednostek terytorialno-administracyjnych (samorządów), organizacji pozarządowych i innych instytucji, po codzienne kontakty między mieszkańcami, obejmujące m.in. przygraniczny handel.

\section{Ksztaltowanie pogranicza}

Powstanie polsko-rosyjskiego pogranicza w poniemieckich Prusach Wschodnich związane było z kształtowaniem powojennego ładu międzynarodowego. W lutym 1945 r. w Jałcie, przywódcy trzech mocarstw potwierdzili ustalenia z Teheranu o podziale Prus Wschodnich między Polskę i ZSRR. W Poczdamie postanowiono, że ostateczny kształt granicy będzie uzgodniony na przyszłej konferencji pokojowej (Teheran, 1972, s. 473-476; szerzej: Kudrzycki, 2013, s. 31-68; Kotowicz, 2012, s. 58-69).

Umowę o polsko-radzieckiej granicy państwowej podpisano 16 sierpnia 1945 r., a ogłoszono ją w 1947 r. ${ }^{2}$ Wspólna komisja dokonała demarkacji, tj. wyznaczenia przebiegu granicy w terenie do kwietnia 1947 r., ale w okresie późniejszym Rosjanie jednostronnie zmieniali jej przebieg na swoją korzyść. Pierwotna granica polsko-radziecka została w niektórych miejscach przesunięta nawet o $30 \mathrm{~km}$ na południe, a jak się szacuje - Polska utraciła ponad $1100 \mathrm{~km}^{2}$ przyznanego jej wcześniej terytorium. $\mathrm{Na}$ przykład, miasto Nordenbork przekazane władzom polskim, zostało później przyłączone do ZSRR i przemianowane na Kryłowo, podobny proces dotknął miasta Pruska Iławka - obecnie Bagrationowsk (Okręg, 1996, s. XVIII-XX; Kostrzak, 1999, s. 99; Wakar, 1992; Kudrzycki, 2013, s. 97-168). „Prostowanie granicy” miało z punktu widzenia strony radzieckiej m.in. element praktyczny, łatwiej bowiem było wybudować sieć zabezpieczeń, które strzegły strefę militarną jaką niedługo stał się Obwód Kaliningradzki (Sakson, 1998, s. 42). Wytyczenie jej w terenie dokonane

2 Umowa między Rzeczpospolitą Polską i Związkiem Socjalistycznych Republik Radzieckich o polsko-radzieckiej granicy państwowej (Dz. U. 1947, Nr 35, poz. 167). Jej artykuł 3 określa: „Aż do ostatecznego rozstrzygnięcia zagadnień terytorialnych przy uregulowaniu pokojowym część granicy polsko-radzieckiej, przylegająca do Morza Bałtyckiego, zgodnie z decyzją Konferencji Berlińskiej będzie przebiegała wzdłuż linii od punktu na wschodnim wybrzeżu Zatoki Gdańskiej - ku wschodowi i na północ od miasta Braunsberg (Braniewo), Goldape (Gołdap), do punktu, w którym ta linia zbiega się z linią graniczną opisaną w artykule drugim niniejszej umowy”. 
de facto jednostronnie przez Rosjan, pozbawiło Polskę realnych możliwości wpływu na jej przebieg, rodząc w konsekwencji szereg problemów, np. swobodnej żeglugi po Zalewie Wiślanym i przez Cieśninę Piławską (Modzelewski, 2006b; Bugajski, 2006; Bugajski, 2010; Bojarowicz, 2013; Kotowicz, 2013).

Ostateczny przebieg granicy uregulowano umową z 5 marca 1957 r. ${ }^{3}$, uzupełnioną protokołem z $1958 \mathrm{r}^{4}$, a jej faktyczne wyznaczenie w terenie nastąpiło dopiero pod koniec 1958 r. (Okręg, 1996, s. XVIII-XX; Kudrzycki, 2013, s. 169-213). W okresie późniejszym zawarto jeszcze kilka porozumień doprecyzowujących jej przebieg, m.in. w 1969 r.

3 Umowa między Polską Rzeczpospolitą Ludową a Związkiem Socjalistycznych Republik Radzieckich o wytyczeniu istniejącej polsko-radzieckiej granicy państwowej w części przylegającej do Morza Bałtyckiego, podpisana w Moskwie dnia 5 marca 1957 r. (Dz. U. 1958, Nr 37, poz. 166). W jej Art. 1 czytamy m.in.: „Układające się Strony potwierdzają, że ustalona w $1945 \mathrm{r}$. na Konferencji Berlińskiej i istniejąca obecnie granica państwowa między Polską Rzeczpospolitą Ludową a Związkiem Socjalistycznych Republik Radzieckich w części przylegającej do Morza Bałtyckiego zaczyna się od znaku granicznego nr 1987, ustawionego w miejscu zetknięcia się granic Polskiej Rzeczypospolitej Ludowej, Rosyjskiej Federacyjnej Socjalistycznej Republiki Radzieckiej (Kaliningradzki obwód) i Litewskiej Socjalistycznej Republiki Radzieckiej [...] i dalej biegnie w kierunku na ogół zachodnim $0,5 \mathrm{~km}$ na północ od miejscowości Żytkiejmy, $4 \mathrm{~km}$ na północ od miejscowości Gołdap, $0,5 \mathrm{~km}$ na południe od miejscowości Kryłowo, 3 km na południe od miejscowości Żeleznodorożnyj, 2 km na południe od miejscowości Bagrationowsk, $4 \mathrm{~km}$ na południe od miejscowości Mamonowo, $7 \mathrm{~km}$ na północ od miejscowości Braniewo i dalej »przez Zalew Wiślany (Kaliningradskij Zaliw) i Mierzeję Wiślaną (Bałtijskaja Kosa) do punktu znajdującego się na zachodnim brzegu « wspomnianej mierzei $3 \mathrm{~km}$ na północny wschód od miejscowości Nowa Karczma".

${ }^{4}$ Protokół między Rządem Polskiej Rzeczypospolitej Ludowej a Rządem Związku Socjalistycznych Republik Radzieckich o rozgraniczeniu polskich i radzieckich wód terytorialnych w Zatoce Gdańskiej Morza Bałtyckiego, podpisany w Warszawie dnia 18 marca 1958 r. (Dz. U. 1958, Nr 76, poz. 386). W Art. 1 czytamy: „Linia granicy między wodami terytorialnymi Polskiej Rzeczypospolitej Ludowej i Związku Socjalistycznych Republik Radzieckich biegnie linią prostopadłą do linii brzegu, wyprowadzoną z końcowego punktu polsko-radzieckiej granicy państwowej, znajdującego się na Mierzei Wiślanej do przecięcia z zewnętrzną granicą wód terytorialnych Polskiej Rzeczypospolitej Ludowej. Przedłużenie tej linii w tym samym kierunku do przecięcia z zewnętrzną granicą wód terytorialnych Związku Socjalistycznych Republik Radzieckich stanowi granice wód terytorialnych Związku Radzieckiego".

${ }^{5}$ Umowa między Polską Rzeczpospolitą Ludową a Związkiem Socjalistycznych Republik Radzieckich o przebiegu granicy szelfu kontynentalnego w Zatoce Gdańskiej i w południowo-wschodniej części Morza Bałtyckiego, sporządzona w Warszawie dnia 28 sierpnia 1969 r. (Dz. U. 1970, Nr 15, poz. 127). 
i 1985 r. ${ }^{6}$ Dodać należy, że po zmianach geopolitycznych końca lat 80 . XX wieku, wspólną granice potwierdzono w polsko-rosyjskim traktacie o przyjaznej i dobrosąsiedzkiej współpracy z maja 1992 r. ${ }^{7}$

Sztucznie wyznaczona granica dzieliła Prusy Wschodnie na część polską liczącą 23,8 tys. $\mathrm{km}^{2}$ i radziecką liczącą 13,1 tys. $\mathrm{km}^{2}$ z głównym miastem regionu Królewcem (Königsbergiem) ${ }^{8}$. Na terytorium włączonym do ZSRR powstał we wrześniu 1945 r. Königsberski Specjalny Okręg Wojskowy, przemianowany w kwietniu 1946 r. na Obwód Königsberski. Uwzględniając jego ,garnizonowy” charakter, strategiczne położenie jako miejsca bazy Floty Bałtyckiej, sił lądowych i powietrznych oraz szczególne znaczenie geopolityczne, podjęto decyzję o włączeniu go w skład Rosyjskiej Federacyjnej Socjalistycznej Republiki Radzieckiej mimo, że była ona oddzielona od Obwodu przez inne republiki związkowe (Galcow, 2004, s. 22). Kolejnym dekretem Prezydium Rady Najwyższej ZSRR z lipca 1946 r. zmieniono jego nazwę na Obwód Kaliningradzki, a stolicę na Kaliningrad (Samaja, 1980, s. 17). Późniejszy rozpad Związku Radzieckiego doprowadził do oderwania granic Obwodu od terytorium macierzystego Federacji Rosyjskiej i powstania enklawy rozumianej jako - fragment obszaru lądowego państwa otoczony przez terytorium innego państwa (Łazowski, Zawidzka, 2001, s. 94). W analizowanym przypadku część terytorium państwa, oddzielona jest jednak od terytorium macierzystego terytoriami kilku państw ${ }^{9}$. Obwód Kaliningradzki FR można również określić mianem półenklawy (tj. enklawy mającej granicę morską) lub eksklawy (Joanniemi, 1998; Drozd, 2000; Chełminiak, 2009).

W polskiej części pogranicza w marcu 1945 r. utworzono Okręg IV Prusy Wschodnie, przemianowany (po niewielkich korektach terytorial-

6 Umowa między Polską Rzeczpospolitą Ludową a Związkiem Socjalistycznych Republik Radzieckich o rozgraniczeniu morza terytorialnego (wód terytorialnych), strefy ekonomicznej, strefy rybołówstwa morskiego i szelfu kontynentalnego na Morzu Bałtyckim, sporządzona w Moskwie 17 lipca 1985 r. (Dz. U. 1986, Nr 16, poz. 85).

7 Zob. Traktat między Rzeczpospolitą Polską a Federacją Rosyjską o przyjaznej i dobrosąsiedzkiej współpracy, sporządzony w Moskwie dnia 22 maja 1992 r. (Dz. U. 1993, Nr 61, poz. 291).W jego Art. 2 czytamy: „Strony uznają za nienaruszalną istniejącą między nimi granicę i potwierdzają, że nie mają wobec siebie żadnych roszczeń terytorialnych, jak również nie będą występować z takimi roszczeniami w przyszłości”.

8 Nie można pominąć faktu, że niewielka część Prus Wschodnich na północy, tzw. Kraj Kłajpedzki o powierzchni 2,7 tys. $\mathrm{km}^{2}$ przypadła w 1948 r. Litwie.

9 Z Obwodu do terytorium macierzystego Rosji w prostej linii najbliżej jest przez Litwę i Łotwę (ok. 400 km), ewentualnie przez Litwę i Białoruś lub Polskę i Białoruś. 
nych) na Okręg Mazurski, a od maja 1946 r. na województwo olsztyńskie (Kraft, 1999, s. 533). Do 1975 r. z Obwodem Kaliningradzkim graniczyły województwa: olsztyńskie (na długości $163 \mathrm{~km}$ ), białostockie (46 km) i gdańskie na Mierzei Wiślanej (niecały $1 \mathrm{~km}$ granicy lądowej). Łączna długość granicy wynosiła niecałe $210 \mathrm{~km}$, co stanowiło 16,9\% polskiej granicy ze Związkiem Radzieckim (Anisiewicz, 2012, s. 32). W wyniku reformy z 1975 r. województwo olsztyńskie okrojono z części gmin, przyłączając je do ówczesnych województw: elbląskiego, suwalskiego, ciechanowskiego, ostrołęckiego i toruńskiego (szerzej: Korc, 1997). Zgodnie z nowym podziałem administracyjnym w latach 1975-1998 z Obwodem graniczyły województwa: olsztyńskie (na długości $83 \mathrm{~km}$ ), elbląskie (43,5 km) i suwalskie (83,5 km) (Anisiewicz, 2012, s. 43). Po kolejnej reformie administracyjno-terytorialnej, od 1999 r. województwo warmińsko-mazurskie od północy niemal w całości graniczy z Obwodem Kaliningradzkim FR. Długość polsko-rosyjskiej granicy lądowej wynosi dokładnie 209,83 km, przebiega ona równoleżnikowo ze wschodu na zachód, od tzw. trójstyku granic (Polski, Rosji i Litwy) w pobliżu wsi Żerdziny (województwo warmińsko-mazurskie) i Bolcie (województwo podlaskie), aż po Mierzeję Wiślaną w rejonie Nowej Karczmy - Piaski ${ }^{10}$. Ostatni, zachodni fragment granicy przecina Zalew Wiślany/Kaliningradzki ${ }^{11}$ i wody Zatoki Gdańskiej, a długość wspólnej granicy morskiej wynosi $22,21 \mathrm{~km}$.

\section{Współpraca transgraniczna - historia i wspólczesnośćc ${ }^{12}$}

Na badanym pograniczu do 1955 r. istniał stan ścisłej izolacji; poza współdziałaniem wojsk granicznych, nie było żadnej współpracy transgranicznej. Obwód Kaliningradzki funkcjonował jako zamknięta strefa

10 Przypomnijmy, tu niespełna $1 \mathrm{~km}$ fragment granicy lądowej przypada na województwo pomorskie.

11 Warto dodać, że polsko-rosyjska granica przecina także dwa jeziora: Gołdap (koło miasta o tej samej nazwie) oraz położone bardziej na zachód jezioro Graniczne/Żabińskie niedaleko wsi Żabin Graniczny (gmina Banie Mazurskie).

12 Wobec wielości przedsięwzięć transgranicznych oraz wielowątkowości zagadnienia skupiono się tylko na wskazaniu niektórych porozumień partnerskich oraz podstawowych przejawów współpracy. Na temat współpracy na pograniczu polsko-rosyjskim zob. szereg publikacji autora (np. Modzelewski, 2004; Modzelewski, 2008; Modzelewski, 2014). 
zmilitaryzowana, granicę z Polską uszczelniono zasiekami z drutu kolczastego, codziennie też zaorywano pas graniczny. Charakter granicy uniemożliwiał szerszą i swobodną współpracę między mieszkańcami graniczących regionów (Wojnowski, 1999, s. 252-254). Do pierwszych kontaktów, głównie między oficjalnymi delegacjami z Obwodu i ówczesnego województwa olsztyńskiego doszło dopiero około $1956 \mathrm{r}^{13} \mathrm{Na}$ współpracę transgraniczną w tamtym okresie, składały się głównie wymiany: delegacji partyjnych i z zakładów pracy, młodzieży i zespołów artystycznych np. z okazji obchodów radzieckich i polskich świąt państwowych. Intensywność powiązań, silnie uwarunkowanych politycznie, uzależniona była od aktualnej sytuacji wewnętrznej panującej w obydwu krajach i decyzji podejmowanych na szczeblach rządzących partii (PZPR i KPZR). Ponadto odgórnie kreowano współpracę transgraniczna, wyznaczając jednostki administracyjne Polski i ZSRR, które mogły w niej uczestniczyć. W latach 1956-1975 współpracować z Obwodem mogło jedynie województwo olsztyńskie, a od 1975 r. także nowo utworzone województwo elbląskie. Uniemożliwiono np. podjęcie kontaktów transgranicznych pomiędzy mieszkańcami bezpośrednio przyległego do Obwodu powiatu gołdapskiego, a także nieodległych powiatów oleckiego i ełckiego z województwa suwalskiego, które zostały przypisane do współpracy z Litewską SRR (Anisiewicz, Palmowski, 2014). Jedynymi miejscami przekraczania granicy były wtedy: Braniewo-Mamonowo i Skandawa-Żeleznodorożnyj ${ }^{14}$ oraz Bezledy-Bagrationowsk, a później także Gronowo-Mamonowo ${ }^{15}$, które w zasadzie były zamknięte, udostępniane jedynie w momencie wcześniej ustalonego przejazdu danej grupy ludzi (wg list imiennych) czy składu towarowego.

13 Nie ma jednolitego stanowiska, kiedy miały miejsce pierwsze kontakty oficjeli z województwa olsztyńskiego ze stroną kaliningradzka; przywołana Renata Anisiewicz pisze o 1956 r. (Anisiewicz, 2012), a Edmund Wojnowski o 1955 r. (Wojnowski, 1999), natomiast Feliks Walichnowski we wspomnieniach podaje rok 1957 (Walichnowski, 2000, s. 6-7).

14 Dwa kolejowe Graniczne Punkty Kontrolne bez statusu przejść granicznych, obsługujące ruch towarowy między Polska i ZSRR nie mający charakteru transgranicznego.

$15 \mathrm{Na}$ mocy Zarządzenia Ministra Spraw Wewnętrznych z 20 lutego 1979 r. formalnie powołano przejścia w Bezledach i Gronowie jako „drogowe (lokalnego znaczenia)”, przeznaczone do ruchu „osobowego (tylko dla wymiany delegacji polityczno-społecznych, kulturalnych, sportowych i innych, z województw przygranicznych PRL i ZSRR)". Zob. http://dokumenty.rcl.gov.pl/M1979007005201.pdf. 
Od lat 60. rozpoczęto w miarę regularne spotkania polskich i rosyjskich dziennikarzy prasowych i radiowych, połączone z wymianą materiałów i informacji. Główne zadanie mediów w odniesieniu do kooperacji transgranicznej polegało wtedy na tworzeniu korzystnego propagandowo obrazu sąsiadujących regionów przygranicznych oraz na akcentowaniu roli wymiany transgranicznej $\mathrm{w}$ budowaniu więzi pomiędzy obydwoma krajami, poprzez informowanie o różnych jej przejawach. Kontakty dziennikarzy, podobnie jak inne rodzaje powiązań, podlegały ścisłej kontroli partii (Anisiewicz, 2012, s. 72). W latach 70. podjęto na szerszą skalę współpracę kulturalną, np. Teatru im. Stefana Jaracza (Państwowy, 1986), Muzeum Warmii i Mazur czy Wojewódzkiej Biblioteki Publicznej (Wspótpraca, s. 1-10) w Olsztynie z ich odpowiednikami w Obwodzie. W listopadzie 1972 r. zorganizowano po raz pierwszy w województwie olsztyńskim „Dni Kaliningradu” (Miasto, 1972; Judzińska, 1974; Dni, 1974). Pojawiły się tzw. autobusy przyjaźni, które w ciąu kilku dni objeżdżały sąsiedni region ${ }^{16}$ (Wojnowski, 1999, s. 256), organizowano młodzieżowe obozy, kolonie letnie i wczasy pracownicze. Inną formę kontaktów transgranicznych stanowiło współzawodnictwo w dziedzinie sportu (Urniaż, 2008). Kontakty nawiązały władze lokalne z terenów przygranicznych, m.in. Bartoszyc, Braniewa, Sępopola i Kętrzyna ( W rocznice, 1987; Zobaczyć, 1988).

Przemiany polityczne w ZSRR końca lat 80 . XX wieku wpłynęły na badane pogranicze, $\mathrm{m}$.in. w postaci intensyfikacji ruchu granicznego oraz większej liczby informacji na temat Obwodu i realizowanej z nim współpracy w polskich periodykach (Strychalski, 1987a; Wkrótce, 1987; Reich, 1989). W październiku 1987 r. zwołano nawet Okrąły Stół w Kaliningradzie, gdzie dyskutowano o możliwościach współpracy transgranicznej w kształtujących się, nowych uwarunkowaniach politycznych, zakończony podpisaniem protokołu: O podstawowych kierunkach rozwoju przyjacielskich kontaktów między Obwodem Kaliningradzkim a województwem olsztyńskim (Strychalski, 1987b; Nowy etap, 1987). Ideę „okragłych stołów” dotyczących współpracy na polsko-rosyjskim pograniczu kontynuowano w nowych uwarunkowaniach geopolitycznych;

16 Corocznie wysyłano do Kaliningradu i przyjmowano z tego miasta kilka autokarów turystycznych. W latach 80 . XX w. wznowiono tę inicjatywę, obejmując nią głównie młodzież szkolną i studentów. Organizowano studenckie brygady budowlane liczące po ok. 60 osób, które pracowały w lokalnych przedsiębiorstwach budowlanych. 
zwoływano je we wrześniu 1992 r. w Kaliningradzie i w czerwcu 1993 r. w Olsztynie.

Podsumowując ten okres, można za Renatą Anisiewicz wyróżnić następujące formy polsko-kaliningradzkich powiązań politycznych do 1990 r.: kontakty międzypartyjne oraz między terenowymi organami władzy i administracji, kontakty inspirowane przez towarzystwa przyjaźni polsko-radzieckiej i radziecko-polskiej, wizyty delegacji związków zawodowych, współpraca między lokalnymi środkami masowego przekazu, wizyty delegacji wojskowych i weteranów wojennych oraz w mniejszym zakresie, współpraca organów ścigania i wymiaru sprawiedliwości. Do tego należy dodać powiązania o charakterze społecznym (kultura, sport, edukacja, nauka, turystyka, ochrona zdrowia, kontakty organizacji młodzieżowych itp.) oraz współpracę gospodarczą (Anisiewicz, 2012, s. 56-179). Kooperacja w omawianym okresie była mało intensywna i kontrolowana przez aparat partyjno-państwowy z obu stron, nieinicjowana oddolnie przez społeczności lokalne, była rezultatem postanowień ówczesnych władz $z^{17}$.

Od momentu zniesienia statusu Obwodu jako strefy wojskowej ${ }^{18}$ rozpoczęto inicjowanie oddolnych, autentycznych kontaktów między społecznościami na pograniczu polsko-kaliningradzkim. Bardzo popularne były organizowane w tym czasie wyjazdy do Kaliningradu grup ,turystycznych”, zajmujących się drobnym handlem. W 1992 r. zawarto szereg regulacji traktatowych między Polską a Rosją, w tym Traktat o przyjaznej i dobrosąsiedzkiej współpracy ${ }^{19}$ oraz dwa porozumienia o współpracy transgranicznej ${ }^{20}$, co dało impuls do rozwoju kontaktów na pograniczu.

17 Np. w latach 70. XX w. nazwano jedną z głównych ulic Olsztyna „Kaliningradzka”, jednak na początku lat 90. powrócono do jej pierwotnej nazwy „Dworcowa”. W Kaliningradzie do dnia dzisiejszego jest ulica Olsztyńska.

18 Nastąpiło to na mocy uchwały Rady Ministrów ZSRR z dnia 8 października $1990 \mathrm{r}$.

19 Traktat między Rzeczpospolitą Polską a Federacją Rosyjską o przyjaznej i dobrosąsiedzkiej współpracy z 22 maja 1992 r. (Dz. U. 1993, Nr 61, poz. 291).

20 Porozumienie między Rządem Rzeczypospolitej Polskiej a Rządem Federacji Rosyjskiej o współpracy północno-wschodnich województw RP i Obwodu Kaliningradzkiego FR z 22 maja 1992 r. oraz Umowa między Rządem Rzeczypospolitej Polskiej a Rządem Federacji Rosyjskiej o współpracy transgranicznej z dn. 2 października 1992 r. Warto podkreślić, iż pierwszy dokument jest jedynym tego typu porozumieniem podpisanym przez Polskę, określającym regiony współpracujące, co świadczy o roli, jaką przywiązywano do kontaktów na wspólnym pograniczu. 
Wcześniej jednak podpisano pierwsze umowy na szczeblu regionalnym: Protokół o współpracy pomiędzy Obwodem Kaliningradzkim a województwem elbląskim (październik 1990 r.), Protokół intencji o współpracy Obwodu Kaliningradzkiego, województwa elbląskiego i prowincji Blekinge (czerwiec 1991 r.), Porozumienie o współpracy między wojewodą olsztyńskim a przewodniczącym administracji Obwodu Kaliningradzkiego (listopad 1991 r.) oraz Porozumienie o współpracy między wojewodą szczecińskim a przewodniczącym administracji Obwodu Kaliningradzkiego (grudzień 1991 r.). W roku 1992 umowy partnerskie z Obwodem zawarły województwa: elbląskie, suwalskie i gdańskie.

Należy podkreślić, iż w tym czasie współpracę transgraniczną na szczeblu regionu prowadzili wojewodowie; oni składali podpisy pod tymi porozumieniami, byli też stronami pierwszych euroregionów obejmujących badane pogranicze: „Niemen” (1997 r.) i „Bałtyk” (1998 r.) ${ }^{21}$. W latach 90. wojewodowie: olsztyński, elbląski i suwalski powołali nawet pełnomocników ds. współpracy z Obwodem Kaliningradzkim FR. Na szczeblu regionalnego samorządu, w styczniu 1997 r. sejmik województwa olsztyńskiego zawarł z Obwodem Kaliningradzkim FR umowę dwustronną 22 oraz trójstronną, obejmującą szwedzki region Halland ${ }^{23}$, a w 1998 r. umowę z Dumą Kaliningradzką zawarł sejmik województwa gdańskiego.

Uwarunkowania i możliwości prowadzenia współpracy transgranicznej zmieniły się zasadniczo po polskiej reformie administracyjno-terytorialnej końca lat 90. Kooperacja transgraniczna stała się elementem polityki rozwoju samorządów, służąc realizacji celów zawartych w strategiach rozwoju społeczno-gospodarczego, powstały także jej nowe podmioty: samorządy regionalne i powiatowe. Nowe struktury samorządowe rozpoczęły proces renegocjacji dotychczasowych umów oraz podpisywa-

21 Trzeci działający tu euroregion „Łyna-Ława” powstał w 2003 r. i zrzesza polskie i rosyjskie samorządy lokalne, a samorząd województwa od 2004 r. jest jego członkiem wspierającym.

22 Porozumienie o współpracy pomiędzy Obwodową Dumą Kaliningradzką Obwodu Kaliningradzkiego FR i Sejmikiem Samorządowym Województwa Olsztyńskiego Rzeczypospolitej Polskiej, Olsztyn dn. 23 stycznia 1997 r.

${ }^{23}$ Porozumienia o współpracy pomiędzy Obwodową Dumą Kaliningradzką Obwodu Kaliningradzkiego FR, Sejmikiem Samorządowym Województwa Olsztyńskiego RP i Kommunförbundet Halland Królestwa Szwecji, zawarte w Olsztynie dn. 23 stycznia $1997 \mathrm{r}$. 
nia nowych, w mniejszym zakresie proces dotyczył wojewodów ${ }^{24}$. Porozumienia podpisali: marszałek województwa warmińsko-mazurskiego i gubernator Obwodu Kaliningradzkiego FR we wrześniu 2001 r. $^{25}$ oraz przewodniczący sejmiku województwa warmińsko-mazurskiego i przewodniczący Dumy Obwodowej w kwietniu 2002 r. ${ }^{26}$ Spoza Warmii i Mazur, porozumienia o współpracy z administracją obwodową podpisały województwa: pomorskie (dwie umowy z lutego 2002 r., podpisane przez marszałka i przewodniczącego sejmiku) i zachodniopomorskie (w $2004 \mathrm{r}$. zawarta przez marszałka i w 2007 r. przez przewodniczącego sejmiku). Nieuregulowane umowami kontakty z Obwodem prowadzą województwa: łódzkie, lubelskie, podlaskie i podkarpackie.

Na poziomie lokalnym, wieloletnia tradycja oraz bliskość geograficzna determinuje intensywności kontaktów; głównie powiatów i gmin nadgranicznych. Współpracują one ze stroną rosyjską, albo na podstawie umów partnerskich albo w sposób nieformalny, realizując konkretne przedsięwzięcia o charakterze transgranicznym. Każdy z powiatów nadgranicznych województwa warmińsko-mazurskiego ma umowy partnerskie ze stroną rosyjską: braniewski z Zielenogradskiem i Bagrationowskiem, bartoszycki z Bagrationowskiem, kętrzyński z Prawdińskiem i Kaliningradem, węgorzewski z Czerniachowskiem, Ozierskiem i Prawdińskiem (oraz współpracuje bez umowy z Żeleznodorożnym), gołdapski z Gusiewem. Z miast nadgranicznych bardzo aktywne są: Bartoszyce, Braniewo, Gołdap i Węgorzewo.

Łącznie w województwie warmińsko-mazurskim kilkanaście powiatów i ponad 30 gmin ma umowy partnerskie z Obwodem Kaliningradzkim FR, a drugie tyle należy do wspólnych euroregionów lub podejmuje ad hoc współpracę nieformalną. Wśród nich są też samorządy leżące dalej od

24 Nowe porozumienie między wojewodą warmińsko-mazurskim a administracją Obwodu podpisane zostało 19 września 2001 r. i regulowało m.in. kwestie płaszczyzn wzajemnej współpracy, tj. przejścia graniczne, zwalczanie przestępczości, współpracy służb granicznych, celnych, policji i zapobiegania klęskom żywiołowym.

25 Porozumienie o współpracy między województwem warmińsko-mazurskim Rzeczpospolitej Polskiej i administracją Obwodu Kaliningradzkiego Federacji Rosyjskiej, podpisane przez marszałka województwa Andrzeja Ryńskiego i głowę administracji (gubernatora) Władimira Jegorowa, sporządzone w Kaliningradzie dn. 19 września $2001 \mathrm{r}$.

26 Porozumienie o współpracy pomiędzy sejmikiem województwa warmińsko-mazurskiego i Kaliningradzką Dumą Obwodową, sporządzone w Olsztynie dn. 9 kwietnia 2002 r. 
granicy, np. powiat piski współpracuje na podstawie umowy z Mamonowem, ełcki z Ozierskiem, a Olsztynek z Polesskiem. Ze względu na swój potencjał, dwa największe miasta regionu: Olsztyn (dwie umowy z Kaliningradem) i Elblag (umowy z Kaliningradem i Bałtijskiem) realizują w kooperacji ze stroną rosyjską wiele przedsięwzięć o charakterze transgranicznym.

Najważniejsze przejawy współpracy polskich i rosyjskich samorządów to:

- organizacja imprez kulturalnych (np. Dni Kultury Polskiej czy Dni Warmii i Mazur w Obwodzie Kaliningradzkim, Dni Obwodu Kaliningradzkiego na Warmii i Mazurach);

- organizacja targów i konferencji poświęconych problemom współpracy na pograniczu polsko-rosyjskim lub patronat nad nimi;

- promocja i inicjowanie regionalnej współpracy gospodarczej, turystycznej, sportowej oraz wymiany młodzieży;

- wsparcie organizacyjne inicjatyw transgranicznych organizowanych przez organizacje pozarządowe i struktury podległe samorządom;

- realizacja projektów współfinansowanych ze środków UE;

- uczestnictwo w strukturach euroregionalnych;

- udział w pracach Polsko-Rosyjskiej Rady ds. Współpracy Regionów RP z Obwodem Kaliningradzkim FR.

\section{Infrastruktura graniczna}

Stopień kontaktów między obszarami przygranicznymi zależy głównie od specyfiki granicy państwowej, w tym stopnia jej otwartości - przenikalności ${ }^{27}$ (Komornicki, 1999, s. 19). Natężenie ruchu granicznego zależy m.in. od stanu infrastruktury granicznej, liczby przejść oraz ich przepustowości, a przede wszystkim od uregulowań prawnych dotyczących przekraczania granicy.

W dniu 22 maja 1992 r. w Moskwie zawarto Umowę między Rządem Rzeczypospolitej Polskiej a Rządem Federacji Rosyjskiej w sprawie przejść granicznych, która w art. 1 wymienia 3 przejścia kolejowe i 4 drogowe. Uzgodniono, iż terminy ich otwarcia oraz rodzaje ruchu strony

27 Rozumiana jako fizyczna możliwość przekraczania granicy przez ludzi i pojazdy, czyli jej otwartość techniczna, która jest pochodną stopnia sformalizowania granicy jako bariery przestrzennej i stopnia rozwoju infrastruktury transportowej. 
ustalą w drodze wymiany not. Umowa przewidywała udostępnienie przejść do przekraczania granicy przez: osoby, środki transportowe i towary, niezależnie od ich przynależności państwowej w ciągu całej doby. $\mathrm{Na}$ przejściach drogowych przewidywany był ruch pieszy (M.P. 2003, Nr 37, poz. 528).

Kolejowe przejście graniczne Braniewo (Gronowo)-Mamonowo, zostało w pełni otwarte w $1996 \mathrm{r}^{28}{ }^{2}$ i obsługuje jako jedyne z przejść kolejowych ruch osobowy i towarowy, wraz z możliwością dokonania kontroli fitosanitarnej. Ruch osobowy jest tu niewielki, w zależności od popytu okresowo uruchamiany i zamykany, np. realizowano tu połączenia: Gdynia-Kaliningrad i Tczew-Elblag-Kaliningrad. W 2013 r. planowano uruchomienie kolejowego połączenia Olsztyn-Kaliningrad przez Braniewo, jednak inicjatywa nie powiodła się, m.in. ze względu na nikłe zainteresowanie strony rosyjskiej (Nie będzie, 2013; Fiszer). Przejście Skandawa-Żeleznodorożnyj otwarte w 1999 r. obsługuje ruch towarowy polsko-rosyjski, z wyjątkiem towarów wwożonych do Polski podlegających kontroli fitosanitarnej. Natomiast przejście Bartoszyce (Głomno)-Bagrationowsk jest nieczynne.

Drogowe przejście graniczne Bezledy-Bagrationowsk od 1993 r. ma status przejścia międzynarodowego, od 1996 r. obsługuje całodobowo także międzynarodowy ruch towarowy (do 8 ton nacisku na oś), a od 2004 r. ma punkt kontroli weterynaryjnej i fitosanitarnej. Przejście Gronowo-Mamonowo od 1997 r. udostępnione jest dla międzynarodowego ruchu osobowego, a obecnie także towarowego (pojazdów ciężarowych o masie całkowitej do 6 ton). Otwarte w 1995 r. przejście Gołdap-Gusiew od 2002 r. ma status przejścia całodobowego, obsługującego międzynarodowy ruch osobowy i towarowy (z dopuszczalną masą całkowitą do 7,5 tony). Ostatnim z przejść przewidzianych w umowie z 1992 r. jest Grzechotki-Mamonowo (faktycznie Mamonowo II). Uruchomione w grudniu 2010 r., jest największym i najnowocześniejszym przejściem, obsługującym międzynarodowy ruch osobowy i towarowy. Na żadnym z przejść, ze względu na brak zgody strony rosyjskiej, nie jest dopuszczony ruch pieszy (mimo, że przewiduje to umowa w sprawie przejść granicznych), jedynie na przejściu Gołdap-Gusiew można przekraczać granicę rowerem (Przejścia graniczne).

28 Od lat 70. wykorzystywane głównie do celów wojskowych i obsługi koncesjonowanych wizyt. 
Czasowo i w niewielkim zakresie ruch graniczny odbywa się także na dwóch przejściach morskich: we Fromborku i Elblagu ${ }^{29}$. Ponadto, w województwie warmińsko-mazurskim formalnie zlokalizowane jest międzynarodowe przejście lotnicze w Szymanach k. Szczytna, choć od kilku lat jest ono nieczynne ${ }^{30}$.

Należy dodać, iż jedną z płaszczyzn współpracy samorządów Polski i Rosji jest wspólny lobbing na rzecz otwarcia kolejnych przejść granicznych, takich jak: Perły-Kryłowo (gmina Węgorzewo, powiat węgorzewski), Michałkowo-Żeleznodorożnyj (gmina Barciany, powiat kętrzyński), Rapa-Oziersk (gmina Banie Mazurskie, powiat gołdapski), Stopki-Ostre Bardo na rzece Łynie (gmina Sępopol, powiat bartoszycki), Piaski-Bałtijsk na Mierzei Wiślanej (gmina Krynica Morska, powiat nowodworski) oraz Głębock-Korniewo (gmina Lelkowo, powiat braniewski).

\section{Dynamika ruchu granicznego}

Do połowy lat 70. XX wieku łączna liczba przekroczeń granicy w obydwu kierunkach oscylowała wokół 1-3 tys. rocznie. Przemiany demokratyczne zainicjowane w Polsce na początku lat 80 . spowodowały zawieszenie większości powiązań w tym okresie i spadek ruchu granicznego. Jego zdecydowany wzrost nastąpił dopiero pod koniec lat 80. Ogólną liczbę uczestników wymiany transgranicznej z Obwodem Kaliningradzkim w latach 1956-1989 można oszacować na ponad 233 tys. osób, jednak ponad połowa spośród wszystkich przekroczeń granicy miała miejsce w 1988 i 1989 r. (Anisiewicz, 2012, s. 193-194).

Od momentu otwarcia granicy w 1990 r., aż do 1997 r. obserwowano stały, systematyczny wzrost liczby osób ją przekraczających (zob. rys.),

29 W latach 1994-1998 średnio 19,5 tys. osób rocznie przekraczało te dwa przejścia morskie. W 1999 r. nastapił spadek przekroczeń do 9,9 tys., a w latach następnych systematyczny wzrost: 26 tys. (2000 r.), 77 tys. (2001 r.), 64 tys. (2002 r.) i rekordowe 78 tys. (2003 r.). Od 1 stycznia 2004 r. przejścia te obsługuje Morski Oddział Straży Granicznej (zob. Ruch osób, 2014).

30 W latach 1996-2003 regionalny Port Lotniczy Szymany obsługiwał ruch samolotów pasażerskich, obecnie nie prowadzi jednak regularnych połączeń lotniczych. W 2014 r. rozpisano przetarg na wykonawcę terminalu pasażerskiego, do końca 2015 r. planowana jest jego rozbudowa oraz modernizacja pasa startowego, a pierwsze regularne loty mają być wznowione w 2016 r. 
co związane było głównie z dynamicznie rozwijającym się drobnym, przygranicznym handlem. W 1991 r. granicę przekroczyło 117 tys. osób, rok później już 613 tys., a w 1993 r. ponad $1 \mathrm{mln}$. W kolejnych latach dynamika została utrzymana: w 1994 r. - 1,8 mln, w 1995 r. $-2,8 \mathrm{mln}$, w 1996 r. - 4,2 mln, a w 1997 r. rekordowe 5 mln przekroczeń granicy (Ruch osób, 2014). W tym czasie obowiązywała między obu państwami umowa o ruchu bezwizowym z 1979 r. oraz porozumienie o uproszczonym trybie przekraczania granicy z $1985 \mathrm{r}^{31}$

W 1998 r. w związku z kryzysem ekonomicznym w Rosji oraz zaostrzeniem po obu stronach przepisów dotyczących przekraczania grani$\mathrm{cy}^{32}$, nastąpił wyraźny spadek osób przekraczających wspólną granicę (do $3,1 \mathrm{mln}$ ). W kolejnych dwóch latach liczba podróżnych ustabilizowała się na wyższym poziomie 4,2-4,4 mln. W 2001 i 2002 r. nastąpił jednak spadek do 3,9 mln, pogłębiony w 2003 r. do 3,1 mln. Wynikał on m.in. z prowadzenia przez stronę rosyjską dodatkowych opłat granicznych i obowiązkowych ubezpieczeń oraz niewłaściwego traktowania Polaków na granicy, co wywoływało m.in. szereg interwencji polskiego MSZ, konsulatu w Kaliningradzie a nawet Rzecznika Praw Obywatelskich. W 2003 r. wygasło porozumienie o uproszczonym trybie przekraczania granicy, a na mocy umowy z września 2003 r. ${ }^{33}$ wprowadzono reżim wizowy.

Lata 2004-2006 charakteryzuje stabilizacja na poziomie ok. 3,7 mln przekroczeń granicy rocznie. Po wejściu Polski do strefy Schengen w grudniu 2007 r. na badanym pograniczu zaczęły obowiązywać regulacje wynikające z Umowy między Wspólnotą Europejską a Federacją Rosyjską o ułatwieniach w wydawaniu wiz obywatelom Unii Europejskiej i Federacji Rosyjskiej podpisanej 25 maja 2006 r. (Dz. U. UE, L 129). Straciły wtedy moc przepisy umowy polsko-rosyjskiej z 2003 r. umożliwiające wydawanie bezpłatnych wiz w kontaktach polsko-kaliningradz-

31 Zob. Umowa między rządem PRL a rządem ZSRR o wzajemnych podróżach bezwizowych obywateli obu państw z 13 grudnia 1979 r. (Dz. U. 1980, Nr 13, poz. 41) oraz Porozumienie między rządem PRL a rządem ZSRR o uproszczonym trybie przekraczania granicy państwowej przez obywateli zamieszkałych w miejscowościach przygranicznych z 14 maja 1985 r. (Dz. U. 1986, Nr 24, poz. 114).

${ }^{32} \mathrm{~Np}$. w czerwcu 1997 r. uchwalono nową ustawę o cudzoziemcach, która od 1998 r. zaostrzyła obcokrajowcom warunki pobytu w Polsce.

33 Umowa między rządem Rzeczypospolitej Polskiej a Rządem Federacji Rosyjskiej o warunkach podróży obywateli Rzeczypospolitej Polskiej i obywateli Federacji Rosyjskiej, podpisana w Warszawie dn. 18 września 2003 r. (M.P. 2003, Nr 51, poz. 800). 
kich. W efekcie, nastąpił wyraźny spadek przekroczeń wspólnej granicy: do $2,7 \mathrm{mln}$ w 2007 r., pogłębiony do $1,9 \mathrm{mln}$ w $2008 \mathrm{r}$. i do rekordowo niskiego poziomu 1,2 mln w 2009 r. - porównywalnego do roku 1993 (Ruch osób, 2014).

W kolejnych latach widoczne jest powolne odwrócenie tendencji: w 2010 r. liczba przekroczeń wzrosła do 1,4 mln a w 2011 r. do 2,3 mln. Dnia 14 grudnia 2011 r. podpisano polsko-rosyjską umowę o małym ruchu granicznym (MRG), która weszła w życie w lipcu 2012 r. ${ }^{34}$ Przyznała ona przywileje małego ruchu granicznego wszystkim mieszkańcom Obwodu Kaliningradzkiego oraz części województw warmińsko-mazurskiego i pomorskiego (15 powiatów ziemskich oraz aglomeracja trójmiejska, Olsztyn i Elblagg). Od tego momentu obserwujemy dynamizację kontaktów na polsko-rosyjskim pograniczu i gwałtowny wzrost ruchu granicznego: w 2012 r. wyniósł ponad 4,7 mln (zbliżając się tym samym do rekordowego wyniku z 1997 r.), a w 2013 r. przekroczył już 6 mln. Tendencja ta jest utrzymana, bowiem jedynie w 1 półroczu 2014 r. odnotowano 3,2 mln przekroczeń granicy (zob. rys.).

Odnosząc powyższe dane do całości ruchu na polskich granicach, w 1991 r. przekroczenia granicy polsko-rosyjskiej (117 tys.) stanowiły zaledwie $0,1 \%$ ogółu przekroczeń $(114 \mathrm{mln})$, a w rekordowym $1997 \mathrm{r}$. wzrosły do 1,8\% (5 mln wobec $271 \mathrm{mln}$ ). W 2013 r. granicę zewnętrzną UE w Polsce przekroczyło 31,8 mln osób, z czego ok. 20\% polsko-rosyjską (Badanie obrotu).

Zmienił się charakter transgranicznej wymiany osobowej; w latach 90. $\mathrm{XX}$ wieku dominowały wyjazdy o charakterze zarobkowym, związane $\mathrm{z}$ drobnym handlem bazarowym a często nielegalnym przemytem. Obecnie, polska część pogranicza m.in. ze względu na swoje walory przyrodnicze i atrakcyjne ceny, jest coraz chętniej odwiedzana przez Rosjan, którzy przyjeżdżają tu na dłużej, korzystając z bazy hotelowej i różnych form rekreacyjno-wypoczynkowych, robią też zakupy w przygranicznych skle$\operatorname{pach}^{35}$ (Wenerski, Kaźmierczuk, 2013). Polacy odwiedzają Obwód nadal

34 Umowa między Rządem Rzeczypospolitej Polskiej a Rządem Federacji Rosyjskiej o zasadach małego ruchu granicznego, podpisana w Moskwie dn. 14 grudnia 2011 r. (Dz. U. 2012, poz. 814).

35 Np. w 17 tys. Braniewie jest kilka sklepów z wielkich sieci dyskontów, a Rosjanie stanowią tam zdecydowaną większość kupujących (nawet $80 \%$ ). Dużą popularnością cieszą się zakupy spożywcze, ale także obuwie, odzież oraz sprzęt AGD i RTV. Zdaniem Rosjan są one tańsze i lepszej jakości niż te dostępne w Kaliningradzie. 
głównie w celach handlowych (zakup paliwa i wyrobów tytoniowych), korzystając z możliwości, jakie dają przepisy o małym ruchu granicznym. W IV kwartale 2013 r. na zasadach MRG badaną granicę przekroczyło 48,9\% Rosjan i 75,7\% Polaków (Badanie obrotu). Według badań przeprowadzonych po polskiej stronie w 2013 r., aż 84\% mieszkańców, 94\% przedsiębiorców oraz $57 \%$ badanych samorządów pozytywnie oceniało funkcjonowanie małego ruchu granicznego (Mały ruch, 2013).

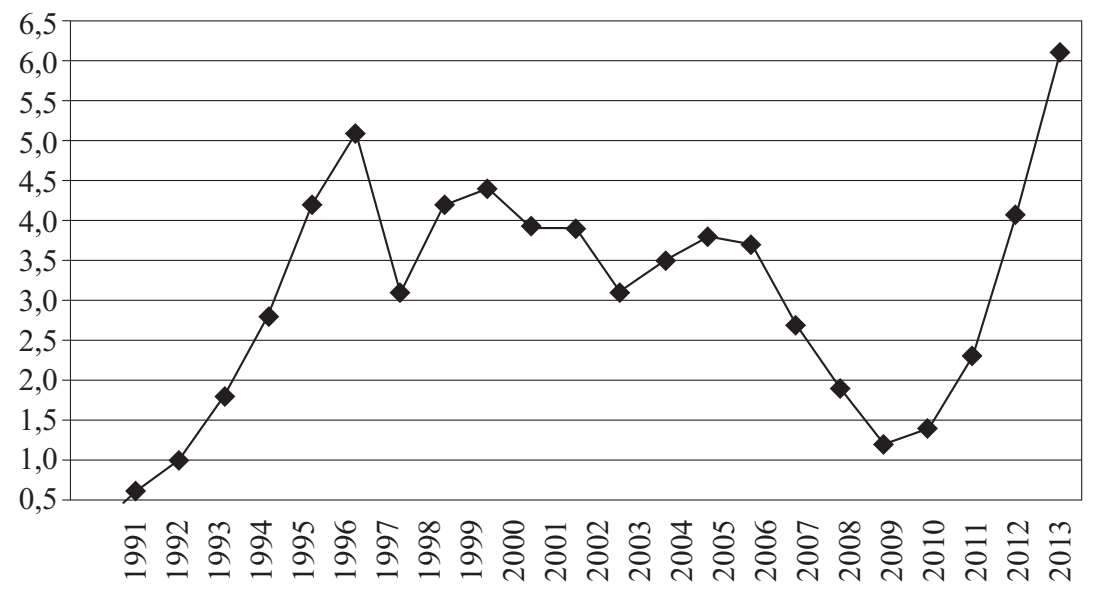

$\neg$ Ruch osób (bez przejść morskich)

Rys. Dynamika ruchu granicznego Polski z Obwodem Kaliningradzkim Źródlo: Opracowanie własne na podstawie danych Warmińsko-Mazurskiego Oddziału Straży Granicznej (Ruch osób, 2014).

Podsumowując, badane pogranicze od 1999 r. jest pograniczem Federacji Rosyjskiej i NATO, a od 2004 r. także Unii Europejskiej, natomiast Obwód Kaliningradzki od 2004 r. stanowi enklawę (półenklawę) wewnątrznatowską i wewnątrzunijną. Wzmacnia to zasadniczo polityczne znaczenie zachodzących tam procesów transgranicznych. Należy je analizować nie tylko przez pryzmat relacji polsko-rosyjskich, ale także w szerszych kontekstach: bałtyckim, europejskim czy euroatlantyckim (Modzelewski, 2006a).

Widoczna jest ewolucja funkcji polsko-rosyjskiej granicy: od bariery przestrzennej i granicy zamkniętej, ,granicy-muru” (do 1955 r.), poprzez granicę otwartą selektywnie (lata 1956-1989), do granicy jako płaszczyzny kooperacji z różnym jej nasileniem, „granicy - mostu” (od 1990 r.). 
Warunkuje to ewolucję pogranicza: od izolowanego, zamkniętego, „martwego", z alienacją regionów przygranicznych - do pogranicza współpracy, otwartego, „żywego”, z koegzystencją regionów przygranicznych. Pamiętając o jego specyfice (granica zewnętrzna UE) i trudnych relacjach politycznych między Polską i Rosją - uprawnionym jest twierdzenie, że intensywna, wieloletnia współpraca transgraniczna oraz wprowadzenie małego ruchu granicznego służą - w dłuższej perspektywie - kształtowaniu wspólnego, polsko-rosyjskiego regionu transgranicznego.

\section{Bibliografia}

Anisiewicz R. (2012), Polska - Obwód Kaliningradzki. Powiqzania transgraniczne przed rokiem 1990, Gdańsk-Pelplin.

Anisiewicz R., Palmowski T. (2014), Wspótpraca transgraniczna z Obwodem Kaliningradzkim w latach 1956-1989, w: Demokracja lokalna a wspótpraca na pograniczu polsko-rosyjskim, red. M. Chełminiak, W. Kotowicz, W. T. Modzelewski, A. Żukowski, Olsztyn.

Badanie obrotu towarów i ushug na zewnętrznej granicy Unii Europejskiej na terenie Polski w IV kwartale 2013 roku, http://old.stat.gov.pl/cps/rde/xbcr/gus/ ch_BAD_OBROT_GRAN_IV_KWARTAl_2013.pdf, 25.07.2014.

Bojarowicz T. (2013), Koncepcja przekopu Mierzei Wiślanej i jej wptyw na relacje polsko-rosyjskie, w: Polska polityka wschodnia a wspótpraca zagraniczna województwa warmińsko-mazurskiego, red. W. Kotowicz, W. T. Modzelewski, A. Żukowski, Olsztyn.

Borys T. (2000), Euroregiony a nowy uklad jednostek terytorialnych Polski, w: Euroregiony - mosty do Europy bez granic, red. W. Malendowski, M. Szczepaniak, Warszawa.

Bugajski D. R. (2006), Polska i międzynarodowa żegluga w Cieśninie Pilawskiej, „Polski Przegląd Dyplomatyczny”, nr 4.

Bugajski D. R. (2010), Nowe rozwiqzania w zakresie żeglugi na Zalewie Wiślanym, „Przegląd Morski”, nr 2.

Chełminiak M. (2009), Obwód Kaliningradzki FR w Europie. Rosyjska enklawa w nowym międzynarodowym tadzie politycznym, Toruń.

Dni Kaliningradu, „Gazeta Olsztyńska” z 7.11.1974 r.

Drozd J. (2000), Królewiec jako szczególny problem Środkowej Europy, „Polityka Wschodnia", nr 1.

Fiszer K., Rosja nie chce pociagów Olsztyn-Kaliningrad, http://www.kurierkolejowy.eu, 25.08.2014. 
Galcow W. I. (2004), Powstanie i główne etapy rozwoju Obwodu Kaliningradzkiego, w: Obwód Kaliningradzki Federacji Rosyjskiej - historia i wspótczesność. Kaliningradskoja obłast Rossijskoj Fiedieracii - istorija i sowriemiennost, red. W. I. Galcow, R. Sudziński, Włocławek.

Gorodiłow A. (1998), Rossja w centrie Jewropy, Kaliningrad.

Granica polsko-radziecka w bytych Prusach Wschodnich (2014), http://historia-wyzynaelblaska.pl, 25.08.2014.

Joanniemi P. (1998), Kaliningrad - Enclave Or Exclave?, w: Kaliningrad: The European Amber Region, red. P. Joenniemi, J. Prawitz, Aldershot-Brookfield.

Judzińska H. (1974), Dni Kaliningradu w Olsztynie, „Gazeta Olsztyńska” z 6.11.1974 r.

Kaliningrad bez korytarza do Moskwy (1990), ,Gazeta Olsztyńska” z 29-30.06.1990 r.

Komornicki T. (1999), Granice Polski. Analiza zmian przenikalności w latach 1990-1996, „Geopolitical Studies”, vol. 5.

Korc E. (1997), Zmiany administracyjno-terytorialne na obszarze bytych Prus Wschodnich, „Komunikaty Mazursko-Warmińskie”, nr 1.

Kostrzak J. (1999), Poczqtki sowieckiej administracji w pótnocnej części Prus Wschodnich w latach 1945-1946, „Studia z dziejów Rosji i Europy Środkowo-Wschodniej”, t. 34.

Kotowicz W. (2012), Życie polityczne Obwodu Kaliningradzkiego FR. Stymulatory endogeniczne i egzogeniczne, Toruń.

Kotowicz W. (2013), Problem Zalewu Wiślanego i Cieśniny Pilawskiej w relacjach polsko-rosyjskich - historia i współczesność, w: Polska polityka wschodnia a wspótpraca zagraniczna województwa warmińsko-mazurskiego, red. W. Kotowicz, W. T. Modzelewski, A. Żukowski, Olsztyn.

Kraft C. (1999), Pierwsze lata w województwie olsztyńskim po II wojnie światowej. Trudne poczatki nowego społeczeństwa, „Komunikaty Mazursko-Warmińskie", nr 4.

Kręta droga do Kaliningradu (1990), „Gazeta Olsztyńska” z 23.08.1990 r.

Kudrzycki Z. (2013), Granica polsko-rosyjska przylegajaca do Morza Battyckiego 1945-1958, Toruń.

Łazowski A., Zawidzka A. (2001), Prawo międzynarodowe publiczne, Warszawa.

Mały ruch w dobrym kierunku. Raport z badania opinii publicznej wśród mieszkańców powiatów objętych Małym Ruchem Granicznym (2013), Centrum Polsko-Rosyjskiego Dialogu i Porozumienia, Warszawa.

Miasto robotników i rybaków (1972), „Gazeta Olsztyńska” z 5.11.1972 r.

Modzelewski W. T. (2004), Wspótpraca na pograniczu polsko-rosyjskim. Wymiar regionalny i lokalny, w: Polska wobec Obwodu Kaliningradzkiego FR, red. A. Żukowski, Olsztyn.

Modzelewski W. T. (2006a), Polska-Obwód Kaliningradzki FR. Polityczne uwarunkowania wspótpracy transgranicznej, Olsztyn. 
Modzelewski W. T. (2006b), Żegluga po Zalewie Wiślanym, jako kwestia sporna w stosunkach polsko-rosyjskich, w: XXI wiek. Era kryzysu czy odnowy kulturowej i politycznej świata?, red. A. Hołub, Olsztyn.

Modzelewski W. T. (2008), Wspótpraca na pograniczu polsko-rosyjskim, w: Polska a Obwód Kaliningradzki Federacji Rosyjskiej. Teraźniejszość i wyzwania przyszłości, red. A. Żukowski, Toruń.

Modzelewski W. T. (2014), Wybrane aspekty polsko-rosyjskiej wspótpracy transgranicznej, w: Demokracja lokalna a wspótpraca na pograniczu polsko-rosyjskim, red. M. Chełminiak, W. Kotowicz, W. T. Modzelewski, A. Żukowski, Olsztyn.

Modzelewski W. T., Żukowski A. (2013), Kategoria pogranicza w politologii. Aspekty teoretyczne i praktyczne, „Pogranicze. Polish Borderlands Studies”, nr 1.

Nie będzie pociagu wakacyjnego Olsztyn-Kaliningrad (2013), PAP z 29.05.2013 r.

Nowy etap na szlaku Olsztyn-Kaliningrad (1987), „Gazeta Olsztyńska” z 7-8.11.1987 r.

Okręg Mazurski w raportach Jakuba Prawina. Wybór dokumentów. 1945 r. (1996), oprac. T. Baryła, Olsztyn.

Państwowy Teatr im. Stefana Jaracza w Olsztynie - Obwodowy Teatr Dramatyczny w Kaliningradzie: kronika wspótpracy 1960-1986 (1986), wybór i oprac. tekstów E. Letkiewicz, Olsztyn.

Pogranicze polsko-rosyjskie. Problemy wspótpracy transgranicznej z Obwodem Kaliningradzkim (2007), red. T. Palmowski, Gdynia-Pelplin.

Pogranicze polsko-ukraińskie. Środowisko. Społeczeństwo. Gospodarka (2005), red. B. Kawałko, A. Miszczuk, Zamość.

Przejścia graniczne, http://www.wm.strazgraniczna.pl/placowki-wmosg/przejscia-graniczne, 25.07.2014.

Reich R. (1989), Dywany i młynki na konserwowe ogórki, „Gazeta Olsztyńska” z 17.02.1989 r.

Ruch osób ogółem Warmińsko-Mazurskiego Oddziału Straży Granicznej-bez przejść morskich (2014), oprac. Warmińsko-Mazurski Oddział Straży Granicznej, przesłane autorowi w dniu 28.07.2014 r.

Sakson A. (1998), Stosunki narodowościowe na Warmii i Mazurach 1945-1997, Poznań.

Samaja Zapadnoja. Sbornik dokumjentow i matieriałow o stanowlenii i razwitii Kaliningradskoj Obłasti 1946-1952 (1980), Kaliningrad.

Strychalski L. (1987a), Pierestrojka po kaliningradzku, „Gazeta Olsztyńska” z 29.05.1987 r.

Strychalski L. (1987b), Trzeba przekroczyć granicę. Nowy etap wspótpracy Olsztyn - Kaliningrad, „Gazeta Olsztyńska” z 7.10.1987 r.

Teheran-Jałta-Poczdam. Dokumenty szefów trzech wielkich mocarstw (1972), Warszawa.

Urniaż J. (2008), Wspótpraca sportowa $w$ regionach warmińsko-mazurskim i kaliningradzkim w latach 1956-2006, Olsztyn. 
W rocznicę Wielkiego Października (1987), „Gazeta Olsztyńska” z 5.11.1987 r.

Wachowiec R. (1991), Waskie drogi wymiany, „Gazeta Olsztyńska” z 18.04.1991 r.

Wakar A. (1992), Martwa granica, „Borussia”, nr 1.

Walichnowski F. (2000), Granica bez celników, Olsztyn.

Wąs M. (2013), Kreska Stalina, „Ale historia”, nr 16, 19.04.2013, http://wyborcza.pl/alehistoria/1,132071,13772598,Kreska_Stalina.html.

Wenerski L., Kaźmierczuk P. (2013), Krajobraz pogranicza. Perspektywy i doświadczenia funkcjonowania małego ruchu granicznego z Obwodem Kaliningradzkim, Warszawa.

Wkrótce towary z Kaliningradu (1987), „Gazeta Olsztyńska” z 12.05.1987 r.

Wojnowski E. (1999), Granica polsko-kaliningradzka 1944-1997, w: Pogranicze z Niemcami a inne pogranicza Polski, red. Z. Kurcz, Wrocław.

Wspótpraca bibliotek i pisarzy olsztyńskich z Kaliningradem - opracowanie WBP w Olsztynie, br. r. wyd.

Zobaczyć i dotknać (1988), „Gazeta Olsztyńska” z 28.12.1988 r.

Żelazny W. (2002), Wielki Euroregion Saar-Lor-Lux-Nadrenia/Palatynat-Walonia jako przestrzeń europejskiego dobrobytu $w$ trakcie poszukiwań swej tożsamości stabilizujacej europejski pokój, w: Wybrane problemyżycia społecznego na pograniczach, red. Z. Kurcz, Wrocław.

Żukowski A. (2002), Pogranicze pótnocno-wschodnie Polski a polska polityka zagraniczna. Refleksje nad perspektywa stosunków z Obwodem Kaliningradzkim, w: Polskie pogranicza a polityka zagraniczna u progu XXI wieku - Raporty, red. R. Stemplowski, A. Żelazo, Warszawa.

\section{Polish-Russian Borderland - from a Closed to a Cross-border Region}

\section{Summary}

This paper assumes that two neighboring regions, that is regions sharing a common land border, namely Warmia and Mazury, and Kaliningrad FR, form the Polish-Russian borderland. It shows the evolution of the Polish-Russian border, from closed (until 1955), through selectively open (1956-1989), to the border as a platform for cooperation (since 1990). This has determined the evolution of borderland research, from research into a closed, isolated border - to a border where multi-dimensional and bottom-up, cross-border contacts are implemented. The introduction of small border traffic rules in 2012 and the following dynamic increase in border traffic, has largely contributed to creating a Polish-Russian cross-border region.

Key words: Polish-Russian borderland, cross-border cooperation, border traffic 